\title{
PENGARUH DANA PIHAK KETIGA DAN RASIO KECUKUPAN MODAL TERHADAP PEMBIAYAAN MURABAHAH
}

\author{
Kresnhanto Aziz \\ Universitas Singaperbangsa Karawang \\ Email: kresnhanto@gmail.com \\ Dian Hakip Nurdiansyah \\ Universitas Singaperbangsa Karawang \\ Email: dian.hakipnurdiansyah@staff.unsika.ac.id
}

\begin{abstract}
This study aims to examine the effect of Third Party Funds and Capital Adequacy Ratio on Murabahah Financing in Indonesia from 2017-2019. This research method uses quantitative approach. The data used in this study comes from financial statements of sharia bank companies in Indonesia for the period of 2017-2019. Then, the data that has been obtained will be analyzed using multiple linear regression analysis and hypothesis testing consisting of the t test and f test with the help from SPSS 23 software. The sampling technique uses non probability sampling with purposive sampling technique. The results of statistical testing show that partially Third Party Funds has positive effect on Murabahah Financing and Capital Adequacy Ratio has positive effect on Murabahah Financing. Meanwhile, simultaneously Third Party Funds and Capital Adequacy Ratio has an effect on Murabahah Financing. Then, the coefficient of determination (R2) was 97,5\%. This shows that Third Party Funds and Capital Adequacy Ratio variables can effect the Murabahah Financing by 97,5\% and the remaining of 2,5\% is influenced by other variables which are not used in this study.
\end{abstract}

Keywords: Third Party Funds, Capital Adequacy Ratio, Murabahah Financing

\begin{abstract}
Abstrak
Penelitian ini bertujuan untuk mengetahui pengaruh Dana Pihak Ketiga (DPK) dan Rasio Kecukupan Modal (CAR) terhadap Pembiayaan Murabahah pada bank umum syariah secara parsial dan simultan. Periode penelitian yang digunakan adalah tahun 2017-2019. <etode penelitian yang digunakan adalah pendekatan kuantitatif. Data yang digunakan dalam penelitian ini berasal dari bank umum syariah yang terdaftar di Bank Indonesia periode 2017-2019. Lalu, data yang telah didapatkan akan dianalisa menggunakan analisis regresi linear berganda dan uji hipotesis yang terdiri dari uji t dan uji f dengan bantuan dari program perangkat lunak SPSS 23. Teknik sampling yang digunakan yaitu non probability sampling dengan teknik purposive sampling. Hasil dari uji secara statistik menunjukkan bahwa secara parsial Dana Pihak Ketiga memiliki pengaruh positif terhadap Pembiayaan Murabahah dan Rasio Kecukupan Modal mempunyai pengaruh positif terhadap Pembiayaan Murabahah. Sementara itu, secara simultan Dana Pihak Ketiga dan Rasio Kecukupan Modal memiliki pengaruh terhadap Pembiayaan Murabahah. Kemudian, koefisien determinasi (R2) sebesar 97,5\%. Hal ini menunjukkan bahwa variabel Dana Pihak Ketiga dan variabel Rasio Kecukupan Modal mampu mempengaruhi Pembiayaan Murabahah sebesar 97,5\% dan sisa 2,5\% berpengaruh oleh variabel-variabel lain yang tidak digunakan dalam penelitian ini.
\end{abstract}

Kata Kunci: Dana Pihak Ketiga, Rasio Kecukupan Modal, Pembiayaan Murabahah 


\section{PENDAHULUAN}

Perbankan di Indonesia sangat membantu untuk kebutuhan serta aktivitas masyarakat, karena perbankan dipercaya untuk mempermudah masyarakat dalam bertransaksi serta urusan-urusan lainnya. Perbankan di Indonesia dibagi menjadi dua, yaitu perbankan konvensional dan perbankan syariah. Negara Indonesia yang mayoritas penduduknya beragama Islam pasti tidak asing dengan yang namanya perbankan Syariah. Perbankan Syariah mempunyai berbagai jenis akad yang bisa digunakan sebagai penyaluran pembiayaan. Akadakad tersebut yaitu terdiri dari murabahah, mudharabah, musyarakah, salam. Istishna', ijarah, dan qardh. Sistem perbankan syariah pada dasarnya yaitu tidak ada bunga atau disebut juga dengan riba. Jadi perbankan syariah melakukan kegiatan-kegiatan perbankan sesuai dengan hukum-hukum islam yang berlaku yang mana jika melanggar maka akan mendapatkan dosa yang besar. Berbeda dengan perbankan konvensional, perbankan syariah juga mempunyai keuntungan bagi para nasabahnya. Adanya perbankan syariah di Indonesia diharapkan untuk memberikan sumbangan terhadap pertumbuhan ekonomi masyarakat melalui pembiayaan-pembiayaan yang dikeluarkan oleh Bank Syariah. Pembiayaan ini juga yang akan menjadi sumber utama penghasilan dari kegiatan operasional bank karena pembiayaan merupakan aktivitas utama perbankan sehingga dapat tercapainya fungsi bank sebagai media intermediasi.

Salah satu pembiayaan tersebut yaitu pembiayaan murabahah. Murabahah adalah salah satu akad yang paling banyak dipakai karena murabahah adalah perjanjian jual beli antara bank dan nasabah yang harga barangnya sudah disepakati oleh kedua pihak tersebut. Pembiayaan murabahah menurut Pasal 1 UU Nomor 10 Tahun 1998 tentang perbankan, pembiayaan berdasarkan prinsip Syariah adalah penyediaan uang atau tagihan yang dipersamakan dengan itu berdasarkan persetujuan atau kesepakatan antara bank dengan pihak lain yang mewajibkan pihak yang dibiayai untuk mengembalikan uang atau tagihan tersebut setelah jangka waktu tertentu dengan imbalan atau bagi hasil.

Dalam pembiayaan suatu bank, ada beberapa rasio yang harus diperhatikan dan salah satunya yaitu rasio kecukupan modal atau yang disebut juga Capital Adequacy Ratio (CAR). Capital Adequacy Ratio (CAR) menurut Puspitasari (2009) adalah rasio keuangan yang bertujuan untuk mengukur kecukupan modal yang dimiliki oleh bank yang berguna untuk menanggung resiko dari pemberian kredit. Jika nilai rasio ini semakin besar maka tingkat rentabilitas usaha semakin baik atau sehat.

Dana Pihak Ketiga (DPK) adalah dana yang dipercayakan oleh masyarakat kepada bank berdasarkan perjanjian penyimpanan dana yang dibuat dalam 3 bentuk, yaitu giro, deposito, dan tabungan. Jika dana pihak ketiga semakin bertambah, maka budget bank akan semakin bertambah pula. Tingkat kepercayaan masyarakat terhadap bank diukur oleh besar atau kecilnya dana yang berhasil dihimpun oleh bank. Sehingga jika pertumbuhan DPK di suatu bank menunjukkan kecenderungan yang menurun, maka akan memperlemah kegiatan operasional bank.

Beberapa penelitian yang membahas permasalahan ini pun sudah pernah dilakukan, namun hasil yang diperoleh berbeda-beda. Penelitian yang 
pernah dilakukan diantaranya oleh Widya (2017) mengenai analisis faktorfaktor yang mempengaruhi pembiayaan murabahah pada perbankan syariah di Indonesia (periode tahun 2013-2016). Variabel yang digunakan adalah DPK, NPF, CAR, dan ROA. Hasil dari penelitiannya menunjukkan bahwa secara parsial, DPK dan ROA berpengaruh positif terhadap pembiayaan murabahah, sedangkan NPF dan CAR berpengeruh negatif terhadap pembiayaan murabahah. Namun secara simultan, DPK, NPF, CAR, dan ROA berpengaruh positif terhadap pembiayaan murabahah bank syariah yang terdaftar dalam Bank Indonesia periode 2013-2016.

Ali (2016) melakukan penelitian mengenai determinan yang mempengaruhi pembiayaan murabahah pada perbankan syariah di Indonesia. Hasil penelitiannya menunjukkan bahwa Dana Pihak Ketiga (DPK), Return On Asset (ROA), dan inflasi berpengaruh positif terhadap pembiayaan murabahah pada perbankan syariah di Indonesia. Capital Adequacy Ratio (CAR) dan suku bunga berpengaruh negatif terhadap pembiayaan murabahah pada perbankan syariah di Indonesia. Sedangkan Non Performing Financing (NPF) dan Biaya Operasional Pendapatan Operasional tidak berpengaruh terhadap pembiayaan murabahah pada perbankan syariah di Indonesia.

Lalu, Aziza (2016) melakukan penelitian mengenai analisis pengaruh Dana Pihak Ketiga (DPK), Non Performing Financing (NPF), Capital Adequacy Ratio (CAR), modal sendiri dan marjin keuntungan terhadap pembiayaan murabahah pada bank unun Indonesia dengan periode tahun 2011-2015. Hasil penelitiannya yaitu berdasarkan uji persial, Dana Pihak Ketiga (DPK), Capital
Adequacy Ratio (CAR), dan Non Performing Financing (NPF) tidak berpengaruh terhadap pembiayaan murabahah, sedangkan variabel yang berpengaruh yaitu modal sendiri dan marjin keuntungan. Sedangkan berdasarkan uji simultan, Dana Pihak Ketiga (DPK), Capital Adequacy Ratio (CAR), Non Performing Financing (NPF), modal sendiri dan marjin keuntungan secara bersama-sama (simultan) berpengaruh terhadap pembiayaan murabahah pada bank umum syariah.

Berdasarkan perbedaan hasil penelitian terdahulu yang telah dipaparkan beserta uraian latar belakang diatas, peneliti memutuskan melakukan penelitian dengan judul "Pengaruh Dana Pihak Ketiga dan Rasio Kecukupan Modal terhadap Pembiayaan Murabahah pada Bank Umum Syariah Periode 2017-2019”.

\section{TINJAUAN PUSTAKA}

\subsection{Dana Pihak Ketiga}

Dana pihak ketiga yaitu dana dari masyarakat yang dititipkan kepada bank syariah, yang penarikannya dapat dilakukan setiap saat tanpa pemberitahuan terlebih dahulu kepada bank dengan media penarikan tertentu (Sari, 2017). Dana Pihak Ketiga biasanya lebih dikenal dengan dana masyarakat, merupakan dana yang dihimpun oleh bank yang berasal dari masyrakat individu, maupun badan usaha (Ismail, 2010). Dana pihak ketiga sangatlah penting bagi bank dalam menghimpun dana, karena pada dasarnya untuk kepentingan usahanya bank menghimpun dana dari bank itu sendiri (pihak kesatu), dana yang berasal dari pihak lain (dana pihak kedua) dan dana yang berasal dari masyarakat atau pihak ketiga yang berupa tabungan, deposit serta sumber dana lainnya. Menurut UU 
No.21 Tahun 2008 Tentang Perbankan Syariah, Pasal 1 disebutkan bahwa, "Simpanan adalah dana yang dipercayakan oleh nasabah kepada Bank Syariah dan/atau UUS berdasarkan akad wadi'ah atau akad lain yang tidak bertentangan dengan Prinsip Syariah dalam bentuk giro, tabungan, atau bentuk lainnya yang dipersamakan oleh itu". Dana-dana masyarakat yang disimpan dalam bank merupakan sumber dana terbesar yang paling diandalkan bank yang terdiri dari 3 jenis yaitu dalam bentuk giro, deposito, dan tabungan (Pratami \& Muharam, 2011).

\subsection{Rasio Kecukupan Modal}

Rasio kecukupan modal atau yang disebut juga dengan Capital Adequacy Ratio adalah rasio yang memperlihatkan seberapa jauh seluruh aktiva bank yang mengandung risiko (kredit, penyertaan, surat berharga, dan tagihan pada bank lain) ikut dibiayai dari dana modal bank sendiri, disamping dana-dana yang berasal dari sumber-sumber luar bank yang berasal dari masyarakat, pinjaman dan lain-lain (Nofitasari, 2017). Dengan kata lain Capital Adequacy Ratio (CAR) yaitu rasio kinerja bank untuk menunjang aktiva yang mengandung risiko, misalnya yaitu pembiayaan yang diberikan. Rasio kecukupan modal mengacu pada modal sebuah bank dengan mengacu pada aset tertimbang menurut resiko yang ada (Wahyuni, 2020). Rasio ini bertujuan untuk memastikan bahwa jika dalam aktivitasnya bank mengalami kerugian, maka ketersediaan modal yang dimiliki oleh bank mampu mengcover kerugian tersebut (Aziza \& Mulazid, 2017).

\subsection{Murabahah}

\begin{tabular}{lllr}
\multicolumn{2}{c}{ Murabahah } & adalah & akad \\
pembiayaan & suatu & barang & dengan \\
menegaskan & harga & belinya & kepada
\end{tabular}

pembeli dan pembeli membayarnya dengan harga yang lebih sebagai keuntungan yang disepakati (Soemitra, 2017). Murabahah merupakan bagian terpenting dari jual beli dan prinsip akad ini mendominasi pendapatan bank dari produk-produk yang ada di semua bank islam (Nurbaya \& Wahyudi, 2013). Dalam islam, jual beli sebagai sarana tolong menolong antara sesama umat manusia yang diridhoi oleh Allah SWT. Menurut PSAK 102 paragraf 8, Transaksi murabahah tidak harus dalam bentuk pembayaran tangguh (kredit), melainkan dapat juga dalam bentuk tunai setelah menerima barang, ataupun ditangguhkan dengan membayar sekaligus dikemudian hari. Menurut fatwa DSN-MUI No : 111/DSN-MUI/IX/2017 mengenai hukum dan bentuk murabahah, akad jual beli murabahah boleh dilakukan dalam bentuk bai' al-murabahah al-'adiyyah maupun dalam bentuk bai' al-murabahah li al-amir bi al-syira'.

\subsection{Pembiayaan}

Pembiayaan merupakan aktivitas bank syari'ah dalam menyalurkan dana kepada pihak lain selain bank berdasarkan prinsip syari'ah. Penyaluran dana dalam bentuk pembiayaan didasarkan pada kepercayaan yang diberikan oleh pemilik dana kepada pengguna dana. Pembiayaan pada dasarnya dilakukan atas dasar kepercayaan kepada orang lain atas dana yang diberikan (Lindasari, 2017). Dengan demikian pemberi pembiayaan memberikan kepercayaan kepada orang lain atas dana yang diberikan. Dalam pembiayaan harus benar-benar saling jujur tidak ada kebohongan dan harus bisa dipastikan bahwa pembiayaan atau dana yang diberikan kepada penerima pembiayaan dapat dikembalikan sesuai 
dengan jangka waktu yang sudah disepakati oleh pihak yang terkait. Adapun unsur-unsur pembiayaan yaitu:

a) Adanya dua belah pihak, yaitu pemberi pembiayaan (shahibul maal) dan penerima pembiayaan (mudharib).

b) Adanya kepercayaan shahibul maal kepada mudharib yang didasarkan atas prestasi yaitu potensi mudharib.

c) Adanya persetujuan, berupa kesepakatan pihak shahibul maal dengan pihak lainnya yang berjanji membayar dari mudharib kepasa shahibul maal.

\section{METODE PENELITIAN}

\subsection{Desain Penelitian}

Penelitian ini menggunakan pendekatan kuantitatif, yaitu penelitian yang bersifat deskriptif dan cenderung menggunakan analisis. Jenis penelitian ini menggunakan penelitian asosiatif kausal, yaitu hubungan sebab akibat dimana satu variabel (independen) mempengaruhi satu variabel lain (dependen). Lokasi penelitian dilakukan di website perbankan syariah yang terdaftar di bank Indonesia dan otoritas jasa keuangan. Data untuk variabel independen dan dependen yang diambil berasal dari laporan keuangan triwulan yang dipublikasikan.

\subsection{Definisi Operasional Variabel Penelitian}

a. Variabel Independen

1. Dana Pihak Ketiga

Dana Pihak Ketiga adalah dana yang dipercayakan masyarakat kepada bank dengan perjanjian penyimpanan dana dalam bentuk tabungan, giro, dan deposito atau bentuk lainnya yang dipersamakan dengan itu (Maharani, 2010).
DPK $=$ Giro + Deposito + Tabungan

\section{Rasio Kecukupan Modal}

Rasio Kecukupan Modal adalah rasio kinerja bank untuk mengukur kecukupan modal yang dimiliki bank untuk menunjang aktiva yang mengandung atau menghasilkan resiko (Dendawijaya, 2009).

$$
C A R=\frac{\text { Modal }}{A T M R} \times 100 \%
$$

b. Variabel Dependen

Dalam penelitian ini yang akan menjadi variabel dependen adalah pembiayaan murabahah. Pembiayaan murabahah adalah bentuk pembiayaan yang berprinsip jual beli barang yang pada dasarnya merupakan penjualan dengan biaya perolehan ditambah dengan margin keuntungan tertentu. Pembayarannya bisa dilakukan secara tunai maupun ditangguhkan dan dicicil (Ascarya, 2007). Dalam penelitian ini yang akan menjadi variabel dependen adalah jumlah pembiayaan murabahah pada bank umum syariah.

\subsection{Jenis dan Sumber Data}

Jenis data penelitian yang digunakan yaitu data sekunder. Sumber data penelitian yang didapat dari Laporan Keuangan triwulan yang berasal dari website resmi bank syariah yang terpilih sebagai sampel untuk penelitian ini dengan periode tahun 2017-2019. Waktu pengumpulan data dilakukan pada bulan Mei 2020.

\subsection{Populasi dan Teknik Sampel}

Populasi dalam penelitian ini adalah perbankan syariah yang tercatat di Bank Indonesia dan Otoritas Jasa Keuangan tahun 2017-2019. Perbankan syariah yang menjadi sampel penelitian ini adalah perbankan syariah yang 
terdaftar di Bank Indonesia dan Otoritas Jasa Keuangan.

Teknik sampel yang digunakan dalam penelitian ini yaitu teknik purposive sampling, di mana pemilihan sampel yang dibatasi oleh kriteria tertentu. Kriteria perbankan syariah yang menjadi sampel penelitian ini adalah:

a. Perbankan syariah yang menerbitkan laporan keuangan triwulan periode 2017-2019 dan telah dipublikasikan di Otoritas Jasa Keuangan, Bank Indonesia, atau website masingmasing bank syariah tersebut.

b. Perbankan syariah yang memiliki data yang dibutuhkan terkait pengukuran variabel-variabel yang digunakan untuk penelitian selama periode 2017 2019.

\subsection{Teknik Pengumpulan Data}

Teknik pengumpulan data digunakan dengan metode dokumentasi, yaitu dengan cara mengumpulkan data, mencatat, dan mengkaji data sekunder yang diambil. Pengumpulan data dilakukan dengan mengumpulkan dokumen berupa data laporan keuangan triwulan, melalui website resmi bank syariah yang sudah ditentukan.

\subsection{Metode Analisis Data}

Data yang telah terkumpul akan dilakukan analisis regresi linear berganda dengan bantuan program SPSS 23. Hasil penelitian berupa uji asumsi klasik, analisis regresi linear berganda, dan teknik pengujian hipotesis.

1. Uji Asumsi Klasik

Sebelum melakukan analisis regresi linear berganda dan teknik pengujian hipotesis, terlebih dahulu melakukan uji asumsi klasik yang terdiri dari uji normalitas, uji autokorelasi, uji heteroskedastisitas, dan uji multikolinearitas.

\section{Uji Normalitas}

Uji normalitas bertujuan untuk menguji apakah dalam suatu model regresi, variabel bebas (independen) dan variabel terikat (dependen) mempunyai distribusi yang normal atau tidak. Model regresi yang baik adalah memiliki distribusi data yang normal atau mendekati normal. Uji normalitas yang digunakan yaitu uji Kolmogorov Smirov dengan bantuan program statistik. Pedoman dari uji tersebut adalah jika nilai secara signifikan lebih dari 5\%, maka dapat dikatakan berdistribusi normal, dan sebaliknya jika nilai secara signifikan kurang dari 5\%, maka dikatakan tidak berdistribusi normal.

3. Uji Autokorelasi

Uji Autokorelasi bertujuan untuk menguji apakah dalam suatu model regresi ada korelasi antara kelasahan pada periode $t$ dengan periode $t-1$ (sebelumnya) (Rochaety et al., 2019). Jika terjadi korelasi, maka dinamakan ada problem autokorelasi. Untuk menguji apakah ada atau tidaknya autokorelasi maka dapat dideteksi dengan uji Run Test. Pengambilan keputusan ada atau tidaknya autokorelasi adalah sebagai berikut:

a. Jika nilai Asymp. Sig. (2-tailed) lebih kecil < dari 0,05 maka terdapat gejala autokorelasi.

b. Sebaliknya, jika nilai Asymp. Sig. (2tailed) lebih besar > dari 0,05 maka tidak terdapat gejala autokorelasi.

4. Uji Heteroskedastisitas

Uji Heteroskedastisitas bertujuan menguji apakah dalam model regresi terdapat ketidaksamaan varians dari residual satu pengamatan ke pengamatan lain (Rochaety et al., 2019). Jika varians dari residual satu pengamatan ke pengamatan lain tetap, maka disebut homoskedastisitas, sedangkan sebaliknya 
disebut heteroskedastisitas. Untuk menguji ada atau tidaknya heteroskedastisitas dapat diketahui dengan melalui uji Spearman. Uji Spearman adalah uji hipotesis yang dilakukan dengan cara mengkorelasikan nilai absolut residual dengan masingmasing variabel independen. Dasar pengambilannya keputusannya yaitu jika nilai sig. (2-tailed) atau signifikasi $<5 \%$, maka artinya ada heteroskedastisitas. Sedangkan jika nilai sig. (2-tailed) atau signifikasi $>5 \%$ maka artinya tidak ada heteroskedastisitas.

\section{Uji Multikolinearitas}

Uji Multikolinearitas bertujuan untuk menguji apakah model regresi mempunyai korelasi antar variabel bebas. Model regresi yang baik seharusnya tidak terjadi korelasi diantara variabel independen. Untuk mendeteksi apakah ada tidaknya multikolinearitas di dalam model regresi dapat dilihat dari nilai Tolerance (T) dan Variance Inflation Factor (VIF). Jika nilai VIF < 10 dan nilai $\mathrm{T}$ $>0,01$, maka tidak terjadi multikolinearitas.

6. Model Regresi

Analisis yang digunakan dalam penelitian ini adalah analisis regresi linear berganda dengan menggunakan program SPSS 23. Model persamaan regresi dalam penelitian ini adalah sebagai berikut:

$$
Y=\alpha+\beta_{1} X_{1}+\beta_{2} X_{2}+e
$$

Keterangan:

$\mathrm{Y}=$ Pembiayaan Murabahah

$\alpha=$ Konstanta

$\beta=$ Koefisien Regresi

$\mathrm{X}_{1}=$ Dana Pihak Ketiga

$\mathrm{X}_{2}=$ Rasio Kecukupan Modal

$e=$ Error
Regresi linear berganda digunakan untuk menghitung besarnya pengaruh dua atau lebih variabel bebas terhadap satu variabel terikat dan memprediksi variabel terikat dengan menggunakan dua atau lebih variabel bebas.

7. Teknik Pengujian Hipotesis

a) Koefisien Determinasi (R2)

Koefisien determinasi

merupakan nilai yang digunakan untuk mengukur besarnya kontribusi variabel independen terhadap variasi (naik/turunnya) variabel dependen (Kurniawan \& Yuniarto, 2016). Nilai koefisien determinasi yaitu antara nol dan satu. Semakin kecil nilai $\mathrm{R}^{2}$ maka kemampuan variabel independen dalam menjelaskan variasi variabel dependen amat terbatas. Sebaliknya, jika nilai koefisien determinasi mendekat angka satu maka variabel inedependen memberikan hampir semua informasi yang dibutuhkan untuk memprediksi variasi variabel dependen.

b) Uji Statistik t

Uji t bertujuan untuk mengetahui apakah variabel bebas atau variabel independen $(\mathrm{X})$ secara parsial (sendirisendiri) berpengaruh terhadap variabel terikat atau veriabel dependen (Y). Membandingkan nilai $\mathrm{t}$ dengan $\mathrm{t}$ tabel, jika nilai $\mathrm{t}$ hitung $>\mathrm{t}$ tabel maka ada pengaruh variabel bebas (X) terhadap variabel terikat (Y) atau hipotesis diterima. Sebaliknya jika nilai hitung $\mathrm{t}<\mathrm{t}$ tabel maka tidak ada pengaruh variabel bebas $(\mathrm{X})$ terhadap variabel terikat $(\mathrm{Y})$ atau hipotesis ditolak.

c) Uji Statistik F

Uji $\mathrm{F}$ pada dasarnya menunjukkan apakah ada pengaruh dengan variabel bebas $(\mathrm{X})$ secara simultan (bersama-sama atau gabungan) terhadap variabel terikat 
lain tetap, maka disebut homoskedastisitas, sedangkan sebaliknya disebut heteroskedastisitas. Pengujian ini menggunakan uji Spearman yaitu uji hipotesis yang dilakukan dengan cara mengkorelasikan nilai absolut residual dengan masing-masing variabel independen. Jika nilai sig. (2-tailed) atau signifikasi $<5 \%$, maka artinya ada heteroskedastisitas. Sedangkan jika nilai sig. (2-tailed) atau signifikasi $>5 \%$ maka artinya tidak ada heteroskedastisitas. Uji heteroskedastisitas dalam penelitian ini menunjukkan hasil sebagai berikut:

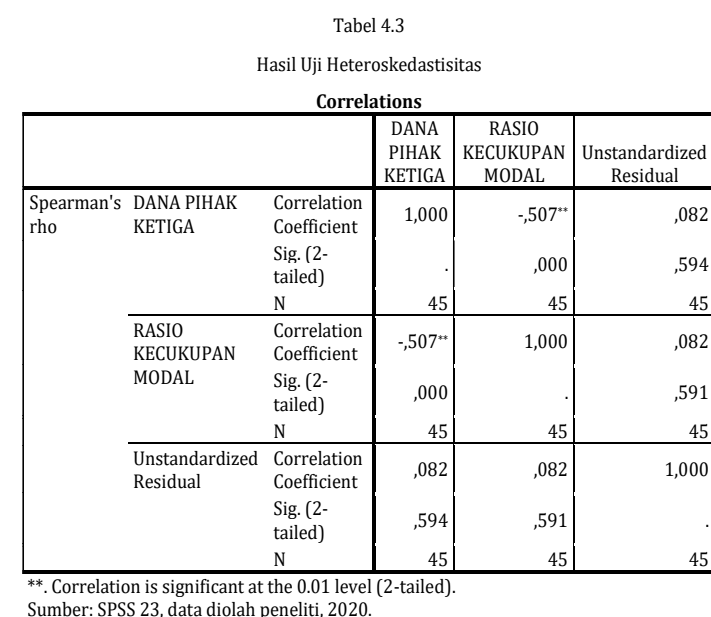

Berdasarkan hasil uji heteroskedastisitas pada tabel 4.3, dapat dilihat nilai signifikasi atau sig. (2-tailed) pada variabel dana pihak ketiga sebesar 0,594 dan nilai signifikasi atau sig. (2tailed) pada variabel rasio kecukupan modal sebesar 0,591. Maka dapat disimpulkan bahwa nilai signifikasi kedua variabel $>0,05$, yang artinya tidak terdapat heteroskedastisitas

d. Uji Multikolinearitas

Uji multikolinearitas dilakukan untuk melihat apakah model regresi mempunyai korelasi antar variabel bebas. Ada atau tidaknya multikolinearitas dalam model regresi dapat dilihat dengan dari nilai Variance Inflation Factor (VIF) dan Tollerance (T). Jika nilai VIF $<10$ dan nilai $\mathrm{T}>0,01$, maka tidak terjadi multikolinieritas. Hasil uji multikolinearitas dapat dilihat pada tabel berikut:

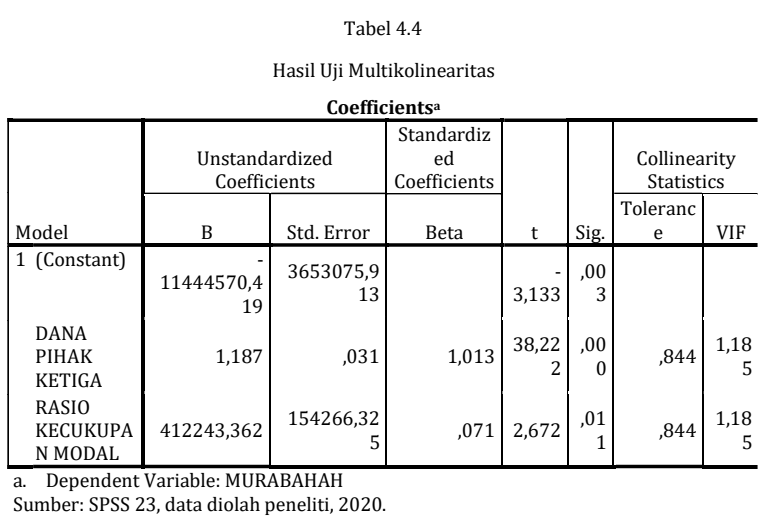

Berdasarkan hasil uji multikolinearitas yang ditunjukkan pada tabel 4.4, dapat dilihat masing-masing variabel DPK dan CAR mendapatkan nilai Tolerance sebesar 0,844 dan nilai VIF sebesar 1,185. Hasil tersebut dapat disimpulkan bahwa model regresi dalam penelitian ini tidak terjadi multikolinearitas dikarenakan hasil nilai Tolerance $>0,01$ dan nilai VIF $<10$.

2. Uji Analisis Regresi Linear Berganda Setelah dilakukan uji asumsi klasik, dapat diperoleh kesimpulan bahwa data penelitian dapat digunakan untuk melakukan analisis regresi linear berganda. Analisis regresi linear berganda digunakan untuk mengetahui hubungan antara variabel independen dengan variabel dependen dengan menggunakan model persamaan linear. Dalam penelitian ini, hubungan variabel yang akan di uji yaitu hubungan Dana Pihak Ketiga (variabel X1) dan Rasio Kecukupan Modal (variabel X2) pada Pembiayaan Murabahah (variabel Y). Berdasarkan hasil pengolahan data penelitian yang dilakukan dengan uji asumsi klasik, hasil uji regresi linear 
berganda dapat diketaui pada tabel di bawah ini:

$$
\text { Tabel } 4.5
$$

Hasil Uji Analisis Regresi Linear Berganda Coefficientsa

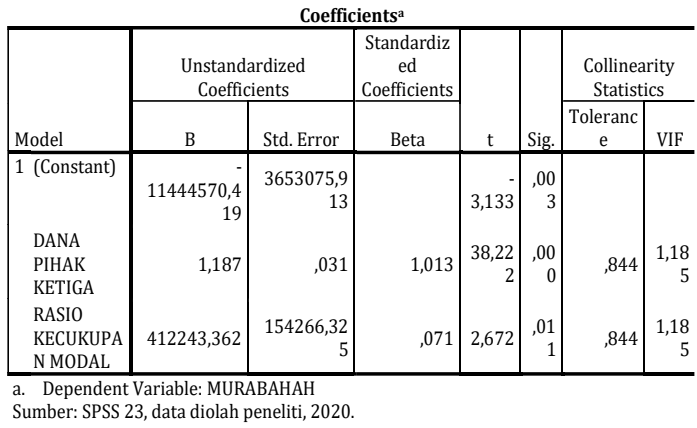

Berdasarkan hasil analisis regresi linear berganda pada tabel 4.5 , dapat diketahui bahwa model persamaan regresi pada penelitian ini adalah sebagai berikut:

$\mathrm{Y}=-11444570,419+1,187 \mathrm{X} 1+$ $412243,362 \mathrm{X} 2+\mathrm{e}$

Hasil modal persamaan regresi di atas juga mendapatkan kesimpulan bahwa:

1) Berdasarkan hasil uji regresi linear berganda di atas, dapat diketahui bahwa nilai (constant) sebesar 11444570,419. Hal ini mengindikasikan bahwa jika variabel independen nilainya adalah 0 , maka nilai Pembiayaan Murabahah menurun sebesar 11444570,419.

2) Variabel Dana Pihak Ketiga mempunyai nilai koefisien sebesar 1,187. Hal ini mengindikasikan bahwa untuk setiap penambahan nilai variabel Dana Pihak Ketiga sebesar 1 (satu), maka nilai variabel Pembiayaan Murabahah akan meningkat sebesar 1,187.

3) Variabel Rasio Kecukupan Modal mempunyai nilai koefisien sebesar 412243,362. Hal ini mengindikasikan bahwa untuk setiap penambahan nilai variabel Rasio Kecukupan Modal sebesar 1 (satu), maka nilai variabel Pembiayaan Murabahah akan meningkat sebesar 412243,362.

3. Analisis Pengujian Hipotesis

a. Uji Koefisien Determinasi (R2)

Uji koefisien determinasi mengukur seberapa jauh kemampuan model dalam menerangkan variabel dependen. Semakin kecil nilai $\mathrm{R}^{2}$ maka kemampuan variabel independen dalam menjelaskan variasi variabel dependen amat terbatas. Sebaliknya, jika nilai koefisien determinasi mendekat angka satu maka variabel inedependen memberikan hampir semua informasi yang dibutuhkan untuk memprediksi variasi variabel dependen. Hasil perhitungan uji koefisien determinasi dapat dilihat pada tabel berikut:

Tabel 4.6

Hasil Uji Koefisien Determinasi

\begin{tabular}{|l|c|r|r|r|c|}
\hline \multicolumn{7}{|c|}{ Model Summaryb } \\
\hline Model & \multicolumn{1}{|c|}{$\mathrm{R}$} & R Square & $\begin{array}{c}\text { Adjusted R } \\
\text { Square }\end{array}$ & $\begin{array}{c}\text { Std. Error of } \\
\text { the Estimate }\end{array}$ & $\begin{array}{c}\text { Durbin- } \\
\text { Watson }\end{array}$ \\
\hline 1 &, $987^{\mathrm{a}}$ &, 975 &, 974 & 3733276,317 & 2,120 \\
\hline
\end{tabular}

a. Predictors: (Constant), RASIO KECUKUPAN MODAL, DANA PIHAK KETIGA b. Dependent Variable: MURABAHAH

Sumber: SPSS 23, data diolah peneliti, 2020.

Berdasarkan tabel 4.9, dapat diketahui bahwa angka $\mathrm{R}^{2}$ yaitu sebesar 0,975. Hal ini berarti bahwa 97,5\% variabel Pembiayaan Murabahah dapat dijelaskan oleh variabel Dana Pihak Ketiga dan Rasio Kecukupan Modal. Sedangkan sisanya sebesar 2,5\% dipengaruhi oleh variabel lain yang tidak termasuk dalam model regresi.

b. Uji Statistikt

Uji statistik $t$ bertujuan untuk mengetahui seberapa besar pengaruh serta signifikasi variabel independen terhadap variabel dependen. Dalam penelitian ini, pengujian dilakukan 
dengan uji-t pada tingkat keyakinan 95\% dengan ketentuan sebagai berikut:

1) Apabila nilai signifikasi $>0,05$, maka $\mathrm{Ho}$ diterima dan $\mathrm{Ha}$ ditolak.

2) Apabila nilai signifikasi $<0,05$, maka $\mathrm{Ho}$ ditolak dan $\mathrm{Ha}$ diterima.

Hasil pengujian masing-masing variabel dapat dijelaskan sebagai berikut:

1) Pengaruh Dana Pihak Ketiga (X1) terhadap Pembiayaan Murabahah (Y)

Berdasarkan hasil uji regresi linear berganda pada tabel 4.5, diperoleh hasil bahwa variabel Dana Pihak Ketiga memiliki nilai t hitung sebesar 38,222 dengan nilai signifikasi sebesar 0,000. Nilai t hitung sebesar 38,222 dan nilai signifikasi sebesar 0,000 lebih kecil dari $0,05(0,000<0,05)$ menunjukkan bahwa Dana Pihak Keitga berpengaruh positif terhadap Pembiayaan Murabahah, sehingga $\mathrm{Ho}_{1}$ ditolak dan $\mathrm{Ha}_{1}$ diterima.

2) Pengaruh Rasio Kecukupan Modal (X2) terhadap Pembiayaan Murabahah (Y)

Berdasarkan hasil uji regresi linear berganda pada tabel 4.5, diperoleh hasil bahwa variabel Rasio Kecukupan Modal memiliki nilai $t$ hitung sebesar 2,672 dengan nilai signifikasi sebesar 0,011. Nilai t hitung sebesar 2,672 dan nilai signifikasi sebesar 0,011 lebih kecil dari $0,05(0,011<0,05)$ menunjukkan bahwa Rasio Kecukupan Modal berpengaruh positif terhadap Pembiayaan Murabahah, sehingga $\mathrm{Ho}_{2}$ ditolak dan $\mathrm{Ha}_{2}$ diterima.

\section{c. Uji Statistik F}

Uji statistik $F$ pada dasarnya menunjukkan apakah semua variabel independen mempunyai penagruh secara simultan (bersama-sama) terhadap variabel dependen. Hasil uji simultan ini dapat dilihat pada tabel dibawah ini:
Tabel 4.7

Hasil Uji Statistik F

\begin{tabular}{|c|c|c|c|c|c|c|}
\hline \multicolumn{7}{|c|}{ ANOVA $^{a}$} \\
\hline \multicolumn{2}{|c|}{ Model } & $\begin{array}{l}\text { Sum of } \\
\text { Squares }\end{array}$ & $\mathrm{df}$ & Mean Square & $\mathrm{F}$ & Sig. \\
\hline 1 & Regression & $\begin{array}{r}2291681373 \\
8798664,000\end{array}$ & 2 & $\begin{array}{r}1145840686 \\
9399332,000\end{array}$ & 822,137 &, $000^{\mathrm{b}}$ \\
\hline & Residual & $\begin{array}{r}5853687863 \\
78910,500\end{array}$ & 42 & $\begin{array}{r}1393735205 \\
6640,727\end{array}$ & & \\
\hline & Total & $\begin{array}{r}2350218252 \\
5177576000\end{array}$ & 44 & & & \\
\hline
\end{tabular}

Berdasarkan hasil uji simultan pada tabel 4.7, diperoleh nilai F hitung sebesar 822,137 dengan nilai siginifikasi sebesar 0,000 . Nilai F hitung sebesar 822,137 dan nilai signifikasi lebih kecil dari 0,05 $(0,000<0,05)$ menunjukkan bahwa Dana Pihak Ketiga dan Rasio Kecukupan Modal secara simultan berpengaruh terhadap Pembiayaan Murabahah bank syariah yang terdaftar di Bank Indonesia periode 2017-2019.

\subsection{Pembahasan}

Berdasarkan hasil penelitian yang telah diuraikan di atas, maka hasil pembahasan dapat dijelaskan sebagai berikut:

1. Pengaruh Dana Pihak Ketiga terhadap Pembiayaan Murabahah

Hasil uji analisis untuk variabel Dana Pihak Ketiga menunjukkan bahwa nilai mean variabel Dana Pihak Ketiga dalam analisis deskriptif sebesar 21766032,15 lebih besar dari nilai standar deviasi yang sebesar 19528220,209 . Hal ini dapat disimpulkan bahwa data dalam penelitian ini terdistribusi secara normal. Jika nilai standar deviasi memiliki nilai yang lebih besar dibandingkan nilai nilai mean, maka data tidak terdistribusi secara normal. Hasil uji analisis lainnya yaitu memiliki nilai $t$ hitung sebesar 38,222 dan nilai signifikan sebesar 0,000 . Nilai t hitung sebesar 38,222 dan nilai signifikasi lebih kecil dari $0,05 \quad(0,000<0,05)$ menunjukkan bahwa Dana Pihak Ketiga 
berpengaruh positif dan signifikan terhadap Pembiayaan Murabahah, sehngga hal ini mendukung $\mathrm{Ha}_{1}$.

Hasil penelitian ini sesuai dengan penelitian yang dilakukan oleh Wardiantika \& Kusumaningtias (2014), Ali (2016), Mizan (2017), Widya (2017), dan Zulfina (2017) yang menyimpulkan bahwa Dana Pihak Ketiga berpengaruh positif dan signifikan terhadap Pembiayaan Murabahah. Sebagian besar penelitian yang terkait menunjukkan hasil bahwa DPK memiliki pengaruh yang positif terhadap Pembiayaan Murabahah. Hal ini dikarenakan setiap kenaikan jumlah DPK yang terkumpul di bank syariah, maka volume pembiayaan murabahah yang disalurkan semakin besar. Hal tersebut juga merupakan tujuan bank syariah untuk mendapatkan profit, sehingga dana yang dimiliki tidak menganggur. Bank cenderung menyalurkan dana semaksimal mungkin untuk mendapatkan keuntungan yang maksimal mungkin pula.

2. Pengaruh Rasio Kecukupan Modal terhadap Pembiayaan Murabahah

Hasil uji analisis untuk variabel Rasio Kecukupan Modal menunjukkan bahwa nilai mean variabel Rasio Kecukupan Modal dalam analisis deskriptif sebesar 21,7198 lebih besar dari nilai standar deviasi yang sebesar 4,34525. Hal ini dapat disimpulkan bahwa data dalam penelitian ini terdistribusi secara normal. Jika nilai standar deviasi memiliki nilai yang lebih besar dibandingkan nilai nilai mean, maka data tidak terdistribusi secara normal. Hasil uji analisis lainnya yaitu memiliki nilai t hitung sebesar 2,672 dan nilai signifikan sebesar 0,011. Nilai t hitung sebesar 2,672 dan nilai signifikasi lebih kecil dari 0,05 $(0,011<0,05)$ menunjukkan bahwa Rasio Kecukupan
Modal berpengaruh positif dan signifikan terhadap Pembiayaan Murabahah, sehingga hal ini mendukung $\mathrm{Ha}_{2}$.

Hasil penelitian ini tidak sesuai dengan penelitian yang dilakukan oleh Ali (2016), Widya (2017), dan Zulfina (2017) yang menyimpulkan bahwa Rasio Kecukupan Modal berpengaruh negatif dan signifikan terhadap Pembiayaan Murabahah. Hasil uji tersebut menunjukkan bahwa modal yang dimiliki bank seharusnya cukup untuk menutupi seluruh risiko yang dihadapi bank. Berdasarkan data bank yang diteliti, dari jumlah sampel bank pada tahun 2018-2019 sebesar 50\% bank memiliki nilai Capital Adequacy Ratio berkisar $18 \%$ hingga $23 \%$ dengan proporsi pembiayaan murabahah sebesar Rp27.313.502juta hingga Rp63.027.393juta. Sedangkan menurut ketentuan Bank Indonesia, bank wajib menyediakan modal minimum sebesar 8\%. Jadi, bank umum syariah dalam penelitian ini memiliki modal serta cadangan modal yang cukup, bila ketika mengalami kerugian dalam pembiayaan murabahah dapat berada pada posisi yang aman.

3. Pengaruh Dana Pihak Ketiga dan Rasio Kecukupan Modal terhadap Pembiayaan Murabahah

Berdasarkan hasil uji $R$ Square $\left(\mathrm{R}^{2}\right)$ pada penelitian ini diperoleh nilai sebesar 0,975. Hal ini berarti besar pengaruh Dana Pihak Ketiga dan Rasio Kecukupan Modal terhadap Pembiayaan Murabahah sebesar 97,5\%, sedangkan sisanya sebesar 2,5\% dipengaruhi oleh variabel lain yang tidak diteliti dalam penelitian ini. Hasil tersebut juga menunjukkan bahwa signifikasi F hitung dalam penelitian ini sebesar 0,000 . Nilai signifikasi tersebut lebih kecil dibandingkan dengan tingkat signifikasi 
yang diharapkan sebesar 0,05, sehingga dapat disimpulkan bahwa Dana Pihak Ketiga dan Rasio Kecukupan Modal secara simultan berpengaruh positif dan signifikan terhadap Pembiayaan Murabahah bank umum syariah yang terdaftar dalam Bank Indonesia pada periode 2017-2019.

\section{PENUTUP}

\subsection{Kesimpulan}

Dari analisis data yang dilakukan untuk mengetahui pengaruh Dana Pihak Ketiga dan Rasio Kecukupan Modal terhadap Pembiayaan Murabahah, maka dapat disimpulkan beberapa hal sebagai berikut:

1. Dana Pihak Ketiga berpengaruh positif terhadap Pembiayaan Murabahah pada bank umum syariah yang terdaftar di Bank Indonesia periode 2017-2019. Hal ini ditunjukkan dengan koefisien regresi yang diperoleh sebesar 1,187 dengan nilai signifikasi sebesar 0,000. Dilihat dari tingkat signifikasi yang lebih kecil dari $0,05(0,000<0,05)$, hasil ini sesuai dengan hipotesis penelitian yang menyatakan bahwa Dana Pihak Ketiga berpengaruh positif dan signifikan terhadap Pembiayaan Murabahah.

2. Rasio Kecukupan Modal berpengaruh positif terhadap Pembiayaan Murabahah pada bank umum syariah yang terdaftar di Bank Indonesia periode 2017-2019. Hal ini ditunjukkan dengan koefisien regresi yang diperoleh sebesar 412243,362 dengan nilai signifikasi sebesar 0,011. Dilihat dari tingkat signifikasi yang lebih kecil dari 0,05 $(0,011<0,05)$, hasil ini sesuai dengan hipotesis penelitian yang menyatakan bahwa Rasio Kecukupan Modal berpengaruh positif dan signifikan terhadap Pembiayaan Murabahah.

\subsection{Saran}

Berdasarkan hasil penelitian yang dikemukakan, maka dapat diberikan saran sebagai berikut:

1. Untuk Managemen bank umum syariah sebaiknya semaksimal mungkin menghimpun DPK dari masyarakat dengan cara mengembangkan prosuk-produk yang efektif dan efisien serta memperhatikan rasio CAR agar tidak mengganggu penyaluran pembiayaan murabahah.

2. Untuk peneliti selanjutnya diharapkan dapat membuat penelitian dengan variabel-variabel lain serta menambah jumlah sampel agar mendapatkan hasil yang lebih akurat dan bervariasi yang dapat menggambarkan pengaruh terhadap pembiayaan murabahah serta menambah periode waktu penelitian sehingga dapat hasil penelitian yang lebih baik lagi.

\section{DAFTAR PUSTAKA}

Ascarya. (2007). Akad dan Produk Bank Syariah. Jakarta: PT Raja Grafindo Persada.

Aziza, R. V. S., \& Mulazid, A. S. (2017). Analisis Pengaruh Dana Pihak Ketiga, Non Performing Financing, Capital Adequacy Ratio, Modal Sendiri dan Marjin Keuntungan Terhadap Pembiayaan Murabahah. JEBI Uurnal Ekonomi Dan Bisnis Islam), 2(1), 1-15.

Dendawijaya, L. (2009). Manajemen Perbankan Edisi Revisi. In Ciawi Bogor, Ghalia Indonesia.

Ismail. (2010). Manajemen Perbankan. In Dari Teori Menuju Aplikasi. Jakarta: Kencana. 
Kurniawan, R., \& Yuniarto, B. (2016). Analisis Regresi Dasar dan Penerapannya dengan R. In Jakarta: PT. Karisma Putra Utama.

Lindasari, I. N. (2017). Penerapan Akad Murabahah Pada Produk Pembiayaan di KSPPS BMT AlHikmah Ungaran Kantor Cabang Gunungpati II. UIN Walisongo.

Maharani, S. D. (2010). Analisis Pengaruh CAR, NPF, dan DPK Terhadap Penyaluran Pembiayaan (Studi Pada Bank Muamalat Indonesia Periode 2001-2009). In Skripsi Program S1 Manajemen Universitas Diponegoro Semarang. Tidak Dipublikasikan.

Nofitasari, Y. (2017). Pengaruh Likuiditas, Rentabilitas, dan Efisiensi Operasional Terhadap Kecukupan Modal PT. Bank Mega Syariah. IAIN Tulungagung.

Nurbaya, F., \& Wahyudi, S. (2013). Analisis Pengaruh CAR, ROA, FDR, dan Dana Pihak Ketiga (DPK) terhadap Pembiayaan Murabahah Periode Maret 2001-Desember 2009 (Studi Kasus pada PT. Bank Muamalat Indonesia, Tbk.). Fakultas Ekonomika dan Bisnis.

Pratami, W. A. N., \& Muharam, H. (2011). Analisis Pengaruh Dana Pihak Ketiga (DPK), Capital Adequacy Ratio (CAR), Non Performing Financing (NPF) dan Return On Asset (ROA) Terhadap Pembiayaan Pada Perbankan Syariah (Studi Kasus Pada Bank Muamalat Indonesia Periode 2001-2011). Universitas Diponegoro.

Rochaety, E., Tresnati, R., \& Latief, A. M. (2019). Metodologi Penelitian Bisnis Dengan Aplikasi SPSS. In Jakarta: Mitra Wacana Media.

Sari, W. (2017). Pengaruh Dana Pihak Ketiga, Non Performing Financing, Capital Adequacy Ratio, dan Return On Asset Terhadap Pembiayaan
Murabahah Pada Perbankan Syariah di Indonesia. Universitas Negeri Yogyakarta.

Soemitra, A. (2017). Bank \& Lembaga Keuangan Syariah. Prenada Media.

Wahyuni, S. (2020). Perbankan Syariah: Pendekatan Penilaian Kinerja. Penerbit Qiara Media. 